\title{
Tocilizumab Effect in COVID-19 Hospitalized Patients: A Systematic Review and Meta- Analysis of Randomized Control Trials
}

\author{
Basheer Abdulrahman ${ }^{1}$, Waleed Aletreby ${ }^{1}$, Ahmed Mady ${ }^{1,2}$, Alfateh Mohammed \\ Noor ${ }^{1}$, Mohammed Lhmdi ${ }^{1}$, Fahad Faqihi ${ }^{1}$, Abdulrahman Alharthy ${ }^{1}$, Mohammed \\ Al-Odat ${ }^{1}$, Dimitrios Karakitsos ${ }^{1,3,}$, Ziad Memish ${ }^{5,6,7}$. \\ 1- Critical Care Department, King Saud Medical City, Riyadh, Saudi Arabia. \\ 2- Anesthesia Department, Faculty of Medicine, Tanta University, Tanta, Egypt. \\ 3- Department of Medicine, South Carolina University School of Medicine, Columbia, SC, USA. \\ 4- Critical Care Department, Keck School of Medicine, University of Southern California, Los \\ Angeles, CA, USA. \\ 5- Research \& Innovation Centre, King Saud Medical City, Riyadh, Saudi Arabia. \\ 6- Hubert Department of Global Health, Rollins School of Public Health, Emory University, \\ Atlanta, GA, USA. \\ 7- College of Medicine, Alfaisal University, Riyadh, Saudi Arabia.
}

\begin{abstract}
Since the emergence of the first cases of COVID-19 viral pneumonia late 2019 several studies evaluated the benefits of different treatment modalities. Early in the pandemic, the interleukin 6 (IL-6) receptor antibody Tocilizumab was considered in view of the cytokine release syndrome associated with COVID-19 infection. Several early observational studies showed beneficial effect of treatment with Tocilizumab on mortality, however, results from well-designed randomized clinical trials (RCT) were contradicting. Objectives: To perform a systematic literature review and meta-analysis of RCTs utilizing Tocilizumab in the treatment of COVID-19 pneumonia, with in-hospital mortality as a primary objective, while secondary objectives included composite outcome of mortality, intubation, or ICU admission, another secondary outcome was super added infection. Method: This was a random effects model (DerSimonian and Laird) model of relative risk (RR), along with corresponding $95 \%$ confidence intervals, $p$ values, and forest plots of both primary and secondary outcomes. A fixed effect sensitivity test was performed for the primary outcome, in addition to subgroup and meta-regression analyses with predefined criteria.

Results: The primary outcome of mortality showed statistically insignificant reduction of mortality with Tocilizumab $(\mathrm{RR}=0.9,95 \% \mathrm{CI}: 0.8-1.01 ; \mathrm{p}=0.09)$ although with an unmistakable apparent clinical benefit. There was a significant reduction in the $R R$ of the secondary composite outcome ( $R R=0.83,95 \%$ CI: $0.76-0.9 ; p$ $<0.001)$, and no difference between groups in super-added infection ( $R R=0.77,95 \% \mathrm{CI}$ : $0.51-1.19 ; \mathrm{p}=0.24)$. Treatment protocol allowing a second dose was the only significant predictor of improved mortality in the metaregression analysis. Certainty of evidence was reduced to moderate for the primary outcome and the secondary outcome of clinical deterioration, while it was reduced to low for the secondary outcome of super-added infection.

Conclusion: Moderate certainty of evidence suggest no statistically significant improvement of 28-30 day all-cause mortality of hospitalized COVID-19 patients treated with TCZ, although there may be clinically important value. Moderate certainty of evidence suggest lowered relative risk of a composite outcome of death or clinical deterioration, while, low grade evidence indicate no increase in the risk of super-added infection associated with TCZ treatment. A protocol allowing two doses of TCZ shows evidence of improved mortality as compared to a strictly single dose protocol.
\end{abstract}




\section{Introduction:}

Since the first case of severe acute respiratory syndrome coronavirus 2 (COVID-19) infection was identified at the end of 2019, COVID-19 has become a huge threat to global health ${ }^{[1,2]}$. The full spectrum of clinical manifestations of COVID-19 ranges from asymptomatic carriage and mild acute respiratory disease, to severe pneumonia and even acute respiratory distress syndrome (ARDS) ${ }^{[3]}$. Although, different mortality reports were coming, most of the deaths were attributed to severe COVID-19 cases ${ }^{[4]}$. COVID-19 is a novel emerging infectious disease associated with a complicated pathogenesis; however, laboratory evidence of severe COVID-19 infections suggests that cytokine release syndrome (CRS) plays a crucial pathogenic role ${ }^{[5]}$. Although many proinflammatory cytokines are involved in CRS, interleukin-6 (IL-6) is the most important, although it was also found to be a poor prognostic factor ${ }^{[6]}$.

Tocilizumab (TCZ) is a humanized monoclonal antibody that can target both membrane-bound and soluble forms of the IL-6 receptor, and several studies have evaluated its efficacy in the treatment of severe COVID-19, tocilizumab use showed a rapid and sustained response and was also associated with significant clinical improvement. By neutralizing a key inflammatory factor in the cytokine release syndrome (CRS), this molecule may block the cytokine storm during the systemic hyper-inflammation stage and reduce disease severity ${ }^{[7,8]}$. In another study by Ramaswamy et al., although tocilizumab-treated patients displayed higher levels of biomarkers [C-reactive protein (CRP) and IL-6] indicative of cytokine storm at initial presentation, tocilizumab still provided a short-term survival benefit ${ }^{[9]}$, such results of observational studies were also reflected in systematic reviews ${ }^{[10]}$. However, contradicting results are emerging from well-designed randomized clinical trials (RCT), indicating lack of such benefit ${ }^{[11]}$, in opposition to other RCTs clearly reflecting clinical and mortality benefits ${ }^{[12]}$.

In view of the conflicting evidence, and the increasing number of published RCTs we aimed to conduct the current systematic literature review to try and fill in the gap of evidence, and consider it as an update of previous reviews that included only observational studies, or those that included both observational and randomized trials.

\section{Objectives:}

The primary objective of the review was to compare 28 - 30 day all-cause mortality among hospitalized patients with confirmed COVID-19 infection whom were given TCZ, to the mortality of similar control patients.

Secondary objectives included the comparison of the same groups with regards to: Combined outcome of death, intubation, or intensive care unit (ICU) admission, and incidence of superinfection.

\section{Method:}

We utilized the PRISMA checklist of preferred reporting items for systematic reviews and metaanalysis. 
medRxiv preprint doi: https://doi.org/10.1101/2021.03.15.21253581; this version posted March 17, 2021. The copyright holder for this preprint (which was not certified by peer review) is the author/funder, who has granted medRxiv a license to display the preprint in perpetuity.

It is made available under a CC-BY 4.0 International license.

\section{Study selection criteria:}

We included only RCTs that compared head to head at least two arms, one receiving TCZ (as intervention arm) and another not receiving TCZ (as the control), if TCZ was being compared to another medication, that medication's group was considered the control, but if the study included more than two arms, the TCZ arm was compared to the control only, without consideration of the third arm, regardless of TCZ dosing regimen.

The included studies must have recruited adult patients (at least 18 years old) with confirmed COVID-19 infection, regardless of other inclusion or exclusion criteria pertaining to the severity of the condition (such as oxygen requirement), or pre-specified laboratory tests' values. Included studies must have also reported at least one of the objectives of this review.

\section{Search strategy:}

We systematically searched for eligible studies in PUBMED, EMBASE, and medical archives (medRxiv) using the keywords: "COVID-19", "SARS-CoV-2", and "Tocilizumab" (details of Pubmed search in supplementary file). Furthermore, we reviewed the list of references of each potentially eligible article for additional studies. The final search list was reviewed by three authors (AB, MA, AW) for final inclusion in the review, any disagreements were resolved by discussion.

\section{Risk of bias (RoB) and quality of evidence assessment:}

Each included study was evaluated independently by 2 authors for RoB using the modified version of the Cochrane Collaboration Tool ${ }^{[13]}$, the tool is built in within the Review Manager ${ }^{\circledR}$ software. The Cochrane Collaboration tool assesses RoB in each included study with regards to 7 domains, namely: random sequence generation, allocation concealment, blinding of participants, blinding of assessors, attrition bias, selective reporting bias, in addition to other sources of bias. Each one of the 7 domains can be evaluated on a 3 level scale as low, unclear, or high risk of bias. The RoB evaluation of each study as well as a summary RoB of included studies were graphically presented.

As for the quality of evidence, we evaluated each outcome according to the GRADE methodology ${ }^{[14]}$, very briefly the methodology evaluates certainty of evidence for a particular outcome after the consideration of 5 criteria: Individual study risk of bias, directness, consistency, precision, and publication bias. Accordingly, generated evidence of each outcome can be graded as: high, moderate, low, or very low.

\section{Data abstracting:}

Each included study was abstracted twice by two independent authors for comparison and validation of consistency. Each author summarized an included study on a pre-prepared excel sheet that included the following information: Last name of first author, year of publication, country, number of patients in intervention and control groups, as well as total number of patients. Data abstracting also included details of inclusion and exclusion criteria, dosing regimen of TCZ, and a list of reported outcome. 


\section{Publication bias assessment:}

We assessed publication bias of the primary outcome using Egger's test (considered significant for publication bias if $\mathrm{p}$ value $<0.05$ ), according to the test result we presented a trim-and-fill funnel plot.

\section{Statistical method:}

Both the primary and secondary objectives of this review were dichotomous outcomes, accordingly, were presented as risk ratio (RR), with corresponding 95\% confidence interval (CI). In view of our anticipation of existing between studies differences, at least in terms of studied populations and TCZ dosing, we used DerSimonian and Laird method in a random effects model to pool the effect size of each outcome, and presented corresponding forest plots, along with corresponding $95 \% \mathrm{CI}$ and p values. For each reported outcome we evaluated heterogeneity using $\mathrm{I}^{2}$ test, and considered heterogeneity among included studies to be high if $\mathrm{I}^{2}$ was higher than $50 \%$. Regardless of the value of $\mathrm{I}^{2}$ test, we a priori planned to perform sub-group analysis of the primary outcome according to severity of enrolled patients, accordingly, included studies were divided into two subgroups, based on whether endotracheal intubation and ICU admission was an exclusion criteria or it was allowed during enrollment, another subgroup analysis was planned based on TCZ dose (single or multiple). Furthermore, we planned a meta-regression analysis for the primary outcome based on the following criteria: patients' severity (dichotomous), TCZ dose (dichotomous single or multiple), and number of recruited patients (continuous). We presented $\log$ odds ratio ( $\log \mathrm{OR}), 95 \% \mathrm{CI}$, and p values of the metaregression.

As a sensitivity test for the primary outcome we also presented RR of the less conservative (narrower CI) fixed effect model ${ }^{[15]}$. All statistical tests and graphs were generated using STATA 14 software (StataCorp. 2015. Stata Statistical Software: Release 14. College Station, TX: StataCorp LP) and Review Manager (RevMan) [Computer program]. Version 5.3. Copenhagen: The Nordic Cochrane Centre, the Cochrane Collaboration, 2014.

The protocol of this study was reviewed and approved by the local institutional review board at King Saud Medical City, Riyadh, Saudi Arabia, under the registration number: H1R1 - 22 - Feb 21-01.

\section{Results:}

Our systematic search in PUBMED, EMBASE, and medXriv databases resulted in the inclusion of 9 articles ${ }^{[11,12,16-22]}$. Eight articles were duplicates between PUBMED and EMBASE, while one article ${ }^{[12]}$ was unique to MedXriv, figure 1 shows the flow diagram of studies' inclusion (details of excluded studies provided in table S1, supplementary file). All studies were randomized clinical trials according to our inclusion criteria with only three double blind studies ${ }^{[11,17,21]}$. Three studies ${ }^{[17,21,22]}$ were multinational studies, the remaining studies although performed in a single country were all multicenter. The included studies recruited a total of 6326 patients, of whom 3272 patients were randomized to the intervention, and 3054 patients were randomized to control group. Included studies had multiple discrepancies among them, the most 
striking was the mechanical ventilation status of recruited patients, as four studies excluded patients if they were mechanically ventilated ${ }^{[11,16-18]}$, whereas in the other five studies patients could be enrolled if they were mechanically ventilated ${ }^{[12,19-22]}$. Only two studies provided TCZ as a single dose ${ }^{[11,19]}$, in the rest of the studies a second dose could be given if the patients were not improving clinically. It's worth noting that the primary outcome of our review (28 - 30 day all-cause mortality) was the primary outcome for only one study ${ }^{[12]}$ (table 1: Details of included studies). Publication bias assessment was done for the nine included studies which all contributed to the primary outcome, and despite fairly visually apparent lack of studies on the left (TCZ) side and apparent asymmetry, the $\mathrm{p}$ value of Egger's test was insignificant ( $\mathrm{p}=$ 0.201), indicating that there is no effect of small studies, however, trim and fill test indicated that 2 studies were missing on the left side (Figure S1, supplementary file).

Our assessment of RoB of the included studies was low in five domains for all studies, whereas the domain of random sequence generation (selection bias) was assessed as unclear in three studies ${ }^{[12,18,19]}$ since these studies didn't report the number of screened patients for eligibility, RoB was also deemed unclear in the "Other" domain for one study, in view of the significant involvement of the sponsor in the study's design, conduct, data collection, and analysis ${ }^{[17]}$. This means that the overall RoB was $100 \%$ low in 5 domains, $67 \%$ low in the selection bias, and $89 \%$ low in "Other" domain (figure $2 \mathrm{a}$ and $\mathrm{b}$ ).

\section{Primary outcome: 28-30 day all-cause mortality:}

In the intervention (TCZ) pooled arm 810 incidences of death occurred within 28-30 days follow up period out of a total of 3272 patients, whereas in the pooled control arm 895 incidences of death occurred within the same follow up period out of 3054 patients. Intuitively, this result indicates lower mortality in the TCZ arm, however, the result just missed statistical significance in the random effects model with $\mathrm{RR}=0.9$ (95\% CI: $0.8-1.01 ; \mathrm{p}=0.09$ ). (Figure 3).

Heterogeneity among the studies included in the primary outcome was very low at $\mathrm{I}^{2}$ value of only $9 \%$, this low heterogeneity is also reflected in an insignificant p value (0.36) of chi square test of heterogeneity. However, this statistically insignificant impact of TCZ on 28-30 day mortality was not robust in our predefined sensitivity test of fixed effect. In the fixed effect model RR $=0.9$ (95\% CI: $0.83-0.97 ; \mathrm{p}=0.008)$.

Interestingly, the primary outcome had very low heterogeneity despite the fact that different populations were included, different doses of TCZ given, and substantially variable sample size for each study. Accordingly, we decided to proceed as planned with our sub-group and metaregression analyses. Subgroup analyses based on the number of TCZ doses indicates that in the two studies allowing only one dose $\mathrm{RR}=2.011$ (95\% CI: $0.97-4.2 ; \mathrm{p}=0.06)$ that is to say there was no statistical difference although clinically the effect was in favor of the control group. On the contrary, in the subgroup of studies that allowed more than one dose of TCZ, there was a statistically significant reduction of mortality in the TCZ group (RR = 0.9, 95\% CI: $0.81-0.96$; $\mathrm{p}=0.003$ ). The second predefined subgroup analysis was based on criteria of inclusion, in the subgroup of studies not recruiting mechanically ventilated patients there was no difference between both groups with regards to mortality $(R R=1.2,95 \% \mathrm{CI}: 0.7-2 ; \mathrm{p}=0.4)$. Similarly, in the subgroup allowing recruitment of mechanically ventilated patients there was no difference in 
medRxiv preprint doi: https://doi.org/10.1101/2021.03.15.21253581; this version posted March 17, 2021. The copyright holder for this preprint (which was not certified by peer review) is the author/funder, who has granted medRxiv a license to display the preprint in perpetuity.

It is made available under a CC-BY 4.0 International license.

mortality as well $(\mathrm{RR}=0.9,95 \% \mathrm{CI}: 0.8-1.1, \mathrm{p}=0.24)$. The supplementary file has more details in figures $\mathrm{S} 3-\mathrm{S} 6)$.

\section{Meta regression:}

Three predefined variables were used to perform the meta-regression, number of TCZ doses (as a binary variable), whether recruitment of mechanically ventilated patients was allowed (as a binary variable), and the total number of recruited patients in each study (as a continuous variable). The only variable with statistical significance was the use of more than one dose of TCZ, as it showed a significant reduction of mortality. For this variable, the coefficient was -0.91 (95\% CI: -0.04 to $-1.77 ; p=0.04$ ). The other two variables were not statistically significant (Details in table S2 and figures S7 - S9 in supplementary file).

\section{Secondary outcomes:}

The first secondary outcome was the combined outcome of either death, intubation, or admission to ICU (we collectively call this outcome: Clinical worsening). Only five out of the included nine studies contributed toward this outcome (figure 4) including 2352 patients in the TCZ arm and 2107 patients in the control arm. There was a statistically significant reduction of this composite outcome with the administration of TCZ, as RR $=0.83$ (95\% CI: $0.76-90 ; p<0.001)$, there was no heterogeneity detected between studies contributing to this outcome $\left(\mathrm{I}^{2}=0 \%\right.$, and chi square test of heterogeneity had an insignificant $\mathrm{p}$ value of 0.45 ).

The second secondary outcome was the safety outcome of super-added infection, six studies contributed to this outcome, that have reported the incidence of infection out of a total of 892 patients who received TCZ, and 551 patients in the control arm. This outcome showed statistically insignificant RR between both arms (RR = 0.77, 95\% CI: $0.51-1.19 ; \mathrm{p}=0.24)$. Figure 5 shows the forest plot of the superadded infection outcome.

\section{Certainty of evidence:}

We utilized the GRADE approach to evaluate the certainty of evidence for our review's three outcomes. The primary outcome of 28-30 day all-cause mortality and the secondary outcome of composite death / intubation / ICU admission were both downgraded once to moderate in view of their relatively wide $95 \% \mathrm{CI}$ and the inclusion of several small studies. The secondary outcome of super-added infection was downgraded twice due to the same reason as the previous two in addition to high heterogeneity with $\mathrm{I}^{2}=53 \%$. Table S3 in supplementary file provides further details.

\section{Discussion:}

This systematic literature review and meta-analysis may not be unique in investigating the effects of TCZ on the outcomes of COVID-19 hospitalized patients, it is -however- the most updated in terms of inclusion of RCTs on the topic, other reviews ${ }^{[23]}$ had fewer published RCTs available to them at the time of their publication, hence, this review could be considered as an update of previously published information. In this review we included a total of 6326 patients from 9 RCTs that compared receiving TCZ plus standard of care (3272 patients) to standard of 
care alone (3054 patients) in the management of hospitalized COVID-19 pneumonia. The intuition of a presumed benefit of Il-6 receptor antagonists arisen early in the COVID-19 era in view of similarities of the pathophysiology of COVID-19 pneumonia to other conditions associated with cytokine release syndrome, such as haemophagocytic lymphohistiocytosis and macrophage activation syndrome ${ }^{[24]}$ and that this cytokine release syndrome is responsible for the multi-organ failure commonly associated with COVID-19 infection, particularly its severe forms ${ }^{[24]}$, accordingly, the use of humanized monoclonal antibodies against IL-6 receptors such as TCZ may mitigate the dysregulated host immune response in COVID-19 infection, and subsequently avoid associated lung tissue damage ${ }^{[5]}$.

These benefits of TCZ particularly on mortality were demonstrated by several observational studies as well as reviews including observational studies ${ }^{[7,10]}$, however, such results are questionable in view of the inherent limitations of observational studies in terms of design, in addition to patients' severity and clinical condition variations ${ }^{[23]}$, furthermore, other reviews failed to demonstrate such benefits, the review by Lan $\mathrm{SH}$ et al ${ }^{[25]}$ concluded no additional benefits of TCZ on mortality, mechanical ventilation, and ICU admission, although these results should also be looked at cautiously, in view of the substantial heterogeneity in all three outcomes, and of course the observational nature of the included studies. What was agreed upon by almost all the early studies and reviews was the need for well-designed randomized clinical trials.

In our review the outcome of short term (28 - 30 day) mortality showed no statistical significance of TCZ, however, this result should be meticulously examined, as it only reports statistical significance, while overlooking potential clinical benefit, the RR was found to be 0.9, however, the $95 \%$ CI was $0.8-1.01$, with an overall effect $\mathrm{p}$ value of 0.09 . While statistically insignificant, we should understand that the significance was only missed by 0.01 in the $95 \%$ CI, more importantly, the result should not be interpreted as lack of effect, but rather as not enough evidence to reject the null hypothesis, and consequently, a clinically meaningful effect can't just be ruled out based solely on statistical results ${ }^{[26]}$. Furthermore, the statistically insignificant result of our primary outcome didn't withstand the sensitivity test of fixed effect model (in fixed effect model $\mathrm{RR}=0.9$, and $95 \% \mathrm{CI}$ ranged between 0.83 and $0.97 ; \mathrm{p}=0.008$ ), although the random effects model is the most valid model of the two in view of differences between studies at least in terms of patients' conditions and doses of TCZ ${ }^{[27]}$. What further strengthens the impression that there could be a meaningful clinical effect of TCZ on mortality despite a statistically insignificant overall effect is the fact that the trim and fill funnel plot (figure S1, supplementary file) indicates two missing studies in favor of TCZ (the left side), that is to say our result may be underpowered. This is supported by the findings of a similar review ${ }^{[23]}$ in which only 5 RCTs were included, and the overall effect on mortality was highly insignificant $(\mathrm{RR}=1.09,95 \% \mathrm{CI}: 0.8-1.49 ; \mathrm{p}=0.57)$, in the study by RECOVERY Collaborative group ${ }^{[12]}$ a meta-analysis section of previously published RCTs was included, in that section the addition of three more RCTs yielded a statistically significant result in favor of TCZ (RR $=0.87,95 \%$ CI: $0.79-0.96 ; \mathrm{p}=0.005)$. While the addition of a ninth small RCT in our review ${ }^{[20]}$ that showed no difference in mortality resulted in widening of the $95 \%$ CI to miss statistical significance. 
Despite the fact that heterogeneity was substantially low (9\%), subgroup analysis a priori determined indicated both a statistically significant and a clinically meaningful reduction of mortality among patients treated with more than one dose of TCZ, regardless of whether critically ill (mechanically ventilated) patients were recruited or not (figure S4, supplementary file). This finding was confirmed in our meta regression analysis, where doses of TCZ (strictly one dose versus possible second dose) was the only significant predictor of lower mortality, in contrast to the severity of recruited patients which proved insignificant in both subgroup and meta regression analyses.

Both of our secondary objectives showed results in favor of treatment with TCZ both statistically and clinically, RR of composite outcome of death, mechanical ventilation, or ICU admission was lower in the group treated with TCZ, while there was no difference in the incidence of superadded infection as a safety measure. Notably, those two secondary outcomes included only five and six studies respectively, indicating under-power.

It is worth mentioning that the certainty of evidence of the primary outcome, and the secondary composite outcome of death, intubation, or ICU admission were both downgraded to "Moderate" in view of imprecision due to the inclusion of small sized studies with few events, and wide confidence intervals. The secondary outcome of super-added infection was downgraded twice to "Low" because of imprecision (previously described) and inconsistency with an $\mathrm{I}^{2}$ test of heterogeneity of $53 \%$.

\section{Conclusion:}

We conclude that moderate certainty of evidence suggest no statistically significant improvement of 28-30 day all-cause mortality of hospitalized COVID-19 patients treated with TCZ, although there may be clinically important value. Moderate certainty of evidence suggest lowered relative risk of a composite outcome of death or clinical deterioration, while, low grade evidence indicate no increase in the risk of super-added infection associated with TCZ treatment. A protocol allowing two doses of TCZ shows evidence of improved mortality as compared to a strictly single dose protocol.

\section{Strengths and Limitations:}

Our review included only RCTs and all available RCTs on the topic to our best knowledge, they were all well-designed with very low levels of RoB. We utilized rigorous statistical methods of meta-analysis, subgroup analysis, and meta-regression, despite low between studies statistical heterogeneity, since clinical heterogeneity was clearly evident at least with regards to study design, blinding, and inclusion criteria.

However, our review is subject to several limitations as well, we included data from one preliminary report of a study available at medRxiv but is still not officially published and accordingly not peer reviewed, although with a high level of validity since it was a very well designed study by a highly trusted group. We also included a small study from China that recruited a limited number of patients (12 patients), and this particular study showed no difference in mortality, but had a very wide $95 \%$ CI, that had an obvious impact on the overall 
effect in the primary outcome. Our review examined three outcomes only, the outcomes that appeared to be most patient centered, however, many more outcomes were studied by the included articles, yet we didn't include them as they were not consistent in the included articles, and investigating them would have resulted in a small number of studies in each outcome.

Finally, the primary outcome of our review was in fact the primary outcome of only one included study, in other words, eight out of nine studies were not sufficiently powered to detect the impact of TCZ on short term mortality.

\section{Financial and Conflicts of interest declaration:}

All authors declare no conflicts of interest during writing of this manuscript. No personal or institutional financial support was received during the writing of this manuscript.

\section{Acknowledgment:}

The authors would like to extend their gratitude to:

Mrs. Huda Mhawish, nursing supervisor of ICU at King Saud Medical City.

Ms. Katrina Baguisa, study coordinator.

Ms. Alva M. Alcazar. Study coordinator. 


\section{References:}

1- Aletreby WT, Alharthy AM, Faqihi F, Mady AF, Ramadan OE, Huwait BM, et al. Dynamics of SARS $\square$ CoV $\square 2$ outbreak in the Kingdom of Saudi Arabia: A predictive model. Saudi Crit Care J 2020;4:79-83.

2- Lai CC, Shih TP, Ko WC, Tang HJ, Hsueh PR. Severe acute respiratory syndrome coronavirus 2 (SARSCoV-2) and coronavirus disease-2019 (COVID-19): the epidemic and the challenges. Int J Antimicrob Agents. 2020;55.

3- Alharthy A, Aletreby W, Faqihi F, Balhamar A, Alaklobi F, Alanezi K, Jaganathan P, Tamim H, Alqahtani SA, Karakitsos D, Memish ZA. Clinical Characteristics and Predictors of 28-Day Mortality in 352 Critically Ill Patients with COVID-19: A Retrospective Study. J Epidemiol Glob Health. 2020 Oct 3.

4- Guan WJ, Ni ZY, Hu Y, Liang WH, Ou CQ, He JX. Clinical characteristics of coronavirus disease 2019 in China. N Engl J Med. 2020;382:1708-1720.

5- Mady A, Aletreby W, Abdulrahman B, Lhmdi M, Noor AM, Alqahtani SA, Soliman I, Alharthy A, Karakitsos D, Memish ZA. Tocilizumab in the treatment of rapidly evolving COVID-19 pneumonia and multifaceted critical illness: A retrospective case series. Ann Med Surg (Lond). 2020 Dec;60:417-424.

6- Zhou F, Yu T, Du R, Fan G, Liu Y, Liu Z. Clinical course and risk factors for mortality of adult inpatients with COVID-19 in Wuhan, China: a retrospective cohort study. Lancet. 2020;395:1054-1062.

7- Capra R, De Rossi N, Mattioli F, Romanelli G, Scarpazza C, Sormani MP. Impact of low dose tocilizumab on mortality rate in patients with COVID-19 related pneumonia. Eur J Intern Med. 2020;76:31-35.

8- Klopfenstein T, Zayet S, Lohse A, Balblanc JC, Badie J, Royer PY. Tocilizumab therapy reduced intensive care unit admissions and/or mortality in COVID-19 patients. Med Mal Infect. 2020 May 6.

9- $\quad$ Ramaswamy M, Mannam P, Comer R, Sinclair E, McQuaid DB, Schmidt ML. Off-label real world experience using tocilizumab for patients hospitalized with COVID-19 disease in a regional community health system: a case-control study. medRxiv. 2020 May 19.

10- $\quad$ Aziz, M, Haghbin, H, Abu Sitta, E, et al. Efficacy of tocilizumab in COVID $\square$ 19: A systematic review and meta $\square$ analysis. J Med Virol. 2021; 93: 1620 1630.

11 - Stone JH, Frigault MJ, Serling-Boyd NJ, Fernandes AD, Harvey L, Foulkes AS, et al. Efficacy of Tocilizumab in Patients Hospitalized with Covid-19. N Engl J Med. 2020 Dec 10;383(24):2333-2344.

12- RECOVERY Collaborative Group, Peter W Horby, Guilherme Pessoa-Amorim, Leon Peto, Christopher E Brightling, Rahuldeb Sarkar, Koshy Thomas, Vandana Jeebun, Abdul Ashish, Redmond Tully, David Chadwick, Muhammad Sharafat, Richard Stewart, Banu Rudran, J Kenneth Baillie, Maya H Buch, Lucy C Chappell, Jeremy N Day, Saul N Furst, Thomas Jaki, Katie Jeffery, Edmund Juszczak, Wei Shen Lim, Alan Montgomery, Andrew Mumford, Kathryn Rowan, Guy Thwaites, Marion Mafham, Richard Haynes, Martin J Landray. Tocilizumab in patients admitted to hospital with COVID-19 (RECOVERY): preliminary results of a randomised, controlled, open-label, platform trial. medRxiv 2021.02.11.21249258.

13- Higgins JPT, Green S, editors. Cochrane Handbook for Systematic Reviews of Interventions Version 5.1.0 [updated March 2011]. In: The Cochrane Collaboration, 2011. Available from: https://training.cochrane.org/handbook.

14- Schünemann H, Brożek J, Guyatt G, Oxman A, editors. GRADE Handbook for Grading Quality of Evidence and Strength of Recommendations. Updated October 2013. The GRADE Working Group, 2013. Available from: https://gdt. gradepro.org/app/handbook/handbook.html.

15- Poole C, Greenland S. Random-effects meta-analyses are not always conservative. Am J Epidemiol. 1999 Sep 1;150(5):469-75.

16- Hermine O, Mariette X, Tharaux PL, Resche-Rigon M, Porcher R, Ravaud P; CORIMUNO-19 Collaborative Group. Effect of Tocilizumab vs Usual Care in Adults Hospitalized With COVID-19 and 
Moderate or Severe Pneumonia: A Randomized Clinical Trial. JAMA Intern Med. 2021 Jan 1;181(1):3240.

17- Salama C, Han J, Yau L, Reiss WG, Kramer B, Neidhart JD, Criner GJ, Kaplan-Lewis E, Baden R, Pandit L, Cameron ML, Garcia-Diaz J, Chávez V, Mekebeb-Reuter M, Lima de Menezes F, Shah R, González-Lara MF, Assman B, Freedman J, Mohan SV. Tocilizumab in Patients Hospitalized with Covid19 Pneumonia. N Engl J Med. 2021 Jan 7;384(1):20-30.

18- Salvarani C, Dolci G, Massari M, Merlo DF, Cavuto S, Savoldi L, Bruzzi P, Boni F, Braglia L, Turrà C, Ballerini PF, Sciascia R, Zammarchi L, Para O, Scotton PG, Inojosa WO, Ravagnani V, Salerno ND, Sainaghi PP, Brignone A, Codeluppi M, Teopompi E, Milesi M, Bertomoro P, Claudio N, Salio M, Falcone M, Cenderello G, Donghi L, Del Bono V, Colombelli PL, Angheben A, Passaro A, Secondo G, Pascale R, Piazza I, Facciolongo N, Costantini M; RCT-TCZ-COVID-19 Study Group. Effect of Tocilizumab vs Standard Care on Clinical Worsening in Patients Hospitalized With COVID-19 Pneumonia: A Randomized Clinical Trial. JAMA Intern Med. 2021 Jan 1;181(1):24-31.

19- Veiga VC, Prats JAGG, Farias DLC, Rosa RG, Dourado LK, Zampieri FG, Machado FR, Lopes RD, Berwanger O, Azevedo LCP, Avezum Á, Lisboa TC, Rojas SSO, Coelho JC, Leite RT, Carvalho JC, Andrade LEC, Sandes AF, Pintão MCT, Castro CG Jr, Santos SV, de Almeida TML, Costa AN, Gebara OCE, de Freitas FGR, Pacheco ES, Machado DJB, Martin J, Conceição FG, Siqueira SRR, Damiani LP, Ishihara LM, Schneider D, de Souza D, Cavalcanti AB, Scheinberg P; Coalition covid-19 Brazil VI Investigators. Effect of tocilizumab on clinical outcomes at 15 days in patients with severe or critical coronavirus disease 2019: randomised controlled trial. BMJ. 2021 Jan 20;372:n84.

20- Zhao H, Zhu Q, Zhang C, Li J, Wei M, Qin Y, Chen G, Wang K, Yu J, Wu Z, Chen X, Wang G. Tocilizumab combined with favipiravir in the treatment of COVID-19: A multicenter trial in a small sample size. Biomed Pharmacother. 2021 Jan;133:110825.

21- Rosas IO, Bräu N, Waters M, Go RC, Hunter BD, Bhagani S, Skiest D, Aziz MS, Cooper N, Douglas IS, Savic S, Youngstein T, Del Sorbo L, Cubillo Gracian A, De La Zerda DJ, Ustianowski A, Bao M, Dimonaco S, Graham E, Matharu B, Spotswood H, Tsai L, Malhotra A. Tocilizumab in Hospitalized Patients with Severe Covid-19 Pneumonia. N Engl J Med. 2021 Feb 25.

22- REMAP-CAP Investigators, Gordon AC, Mouncey PR, Al-Beidh F, Rowan KM, Nichol AD, Arabi YM, Annane D, Beane A, van Bentum-Puijk W, Berry LR, Bhimani Z, Bonten MJM, Bradbury CA, Brunkhorst FM, Buzgau A, Cheng AC, Detry MA, Duffy EJ, Estcourt LJ, Fitzgerald M, Goossens H, Haniffa R, Higgins AM, Hills TE, Horvat CM, Lamontagne F, Lawler PR, Leavis HL, Linstrum KM, Litton E, Lorenzi E, Marshall JC, Mayr FB, McAuley DF, McGlothlin A, McGuinness SP, McVerry BJ, Montgomery SK, Morpeth SC, Murthy S, Orr K, Parke RL, Parker JC, Patanwala AE, Pettilä V, Rademaker E, Santos MS, Saunders CT, Seymour CW, Shankar-Hari M, Sligl WI, Turgeon AF, Turner AM, van de Veerdonk FL, Zarychanski R, Green C, Lewis RJ, Angus DC, McArthur CJ, Berry S, Webb SA, Derde LPG. Interleukin-6 Receptor Antagonists in Critically Ill Patients with Covid-19. N Engl J Med. $2021 \mathrm{Feb} 25$.

23- Tleyjeh IM, Kashour Z, Damlaj M, Riaz M, Tleyjeh H, Altannir M, Altannir Y, Al-tannir M, Tleyjeh R, Hassett L, Kashour T . Efficacy and safety of tocilizumab in COVID-19 patients: a living systematic review and meta-analysis. Clin Microbiol Infect. 2021;27(2):215-227.

24- Vardhana SA, Wolchok JD. The many faces of the anti-COVID immune response. J Exp Med. 2020;217(6):e20200678. doi:10.1084/jem.20200678.

25- $\quad$ Lan SH, Lai CC, Huang HT, Chang SP, Lu LC, Hsueh PR. Tocilizumab for severe COVID-19: a systematic review and meta-analysis. Int J Antimicrob Agents. 2020 Sep;56(3):106103.

26- Schober P, Bossers SM, Schwarte LA. Statistical Significance Versus Clinical Importance of Observed Effect Sizes: What Do P Values and Confidence Intervals Really Represent? Anesth Analg. 2018;126(3):1068-1072. 
medRxiv preprint doi: https://doi.org/10.1101/2021.03.15.21253581; this version posted March 17, 2021. The copyright holder for this preprint (which was not certified by peer review) is the author/funder, who has granted medRxiv a license to display the preprint in perpetuity.

It is made available under a CC-BY 4.0 International license.

27- Jakobsen, J.C., Wetterslev, J., Winkel, P. et al. Thresholds for statistical and clinical significance in systematic reviews with meta-analytic methods. BMC Med Res Methodol 14, 120 (2014). 
medRxiv preprint doi: https://doi.org/10.1101/2021.03.15.21253581; this version posted March 17, 2021. The copyright holder for this preprint (which was not certified by peer review) is the author/funder, who has granted medRxiv a license to display the preprint in perpetuity.

It is made available under a CC-BY 4.0 International license.

Figure 1: Studies inclusion flow diagram:

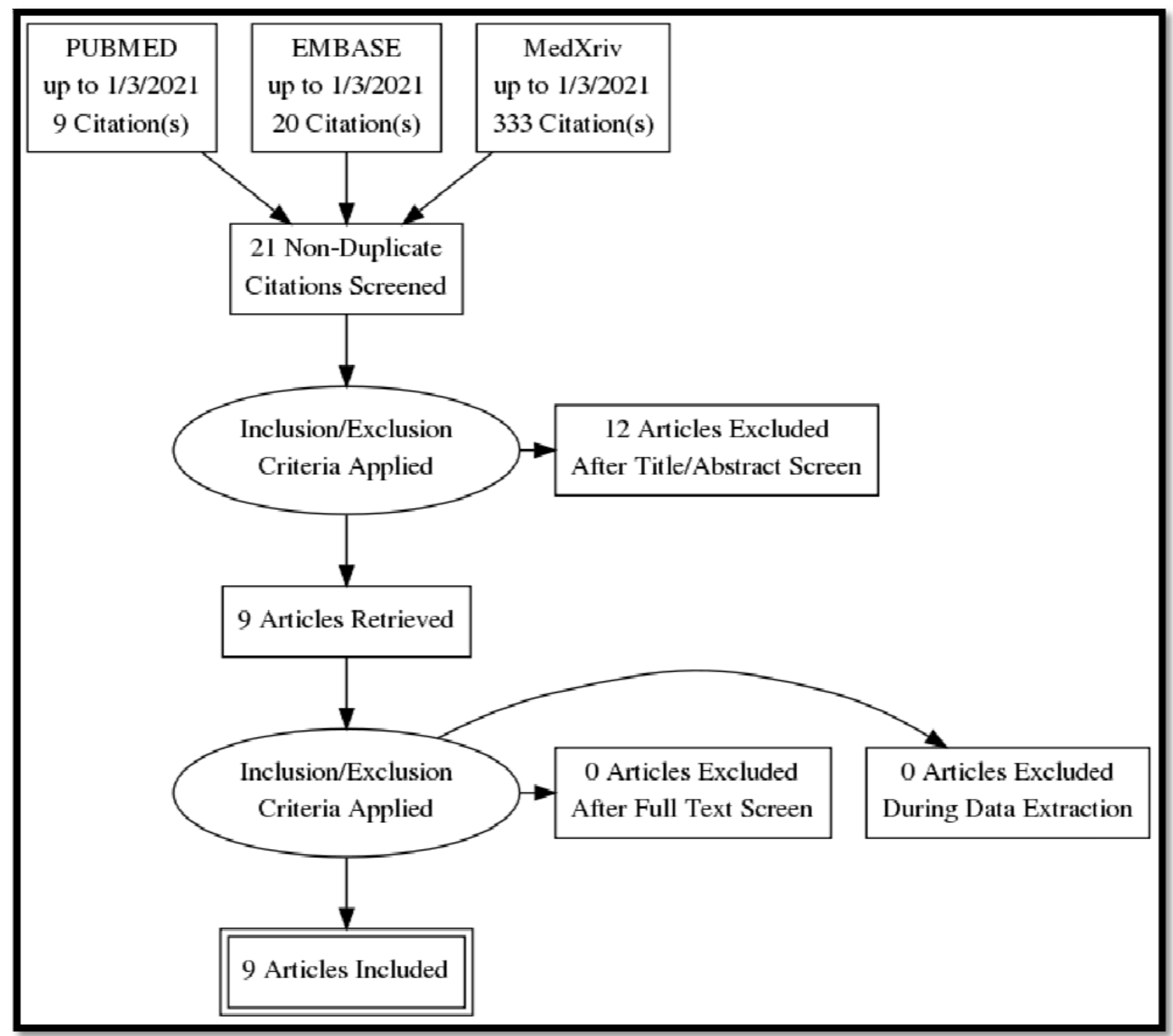


medRxiv preprint doi: https://doi.org/10.1101/2021.03.15.21253581; this version posted March 17, 2021. The copyright holder for this preprint (which was not certified by peer review) is the author/funder, who has granted medRxiv a license to display the preprint in perpetuity.

It is made available under a CC-BY 4.0 International license.

Figure 2: Risk of Bias details and summary:
A: Risk of Bias Details
B: Risk of Bias Summary
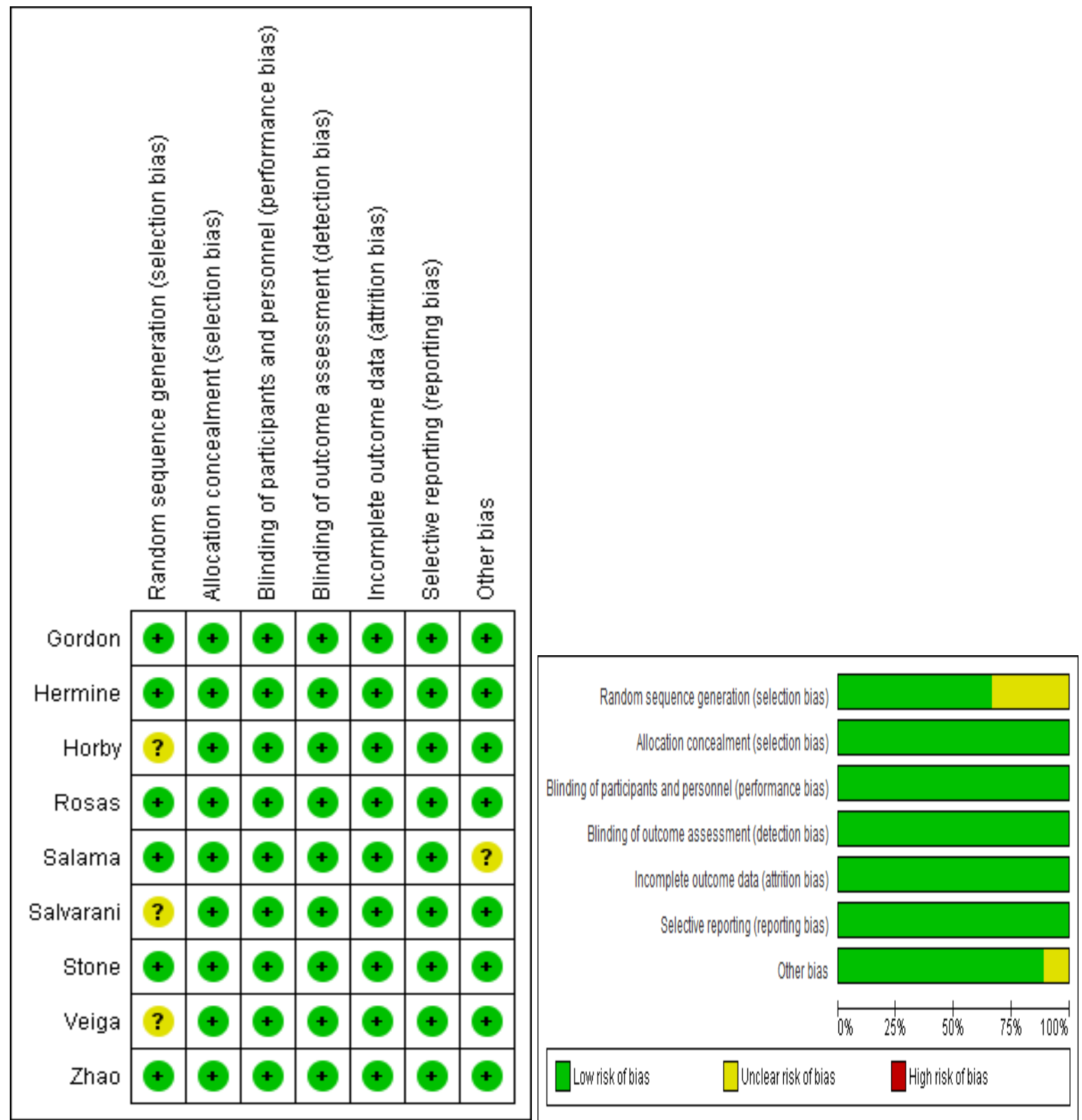
medRxiv preprint doi: https://doi.org/10.1101/2021.03.15.21253581; this version posted March 17, 2021. The copyright holder for this preprint (which was not certified by peer review) is the author/funder, who has granted medRxiv a license to display the preprint in perpetuity.

It is made available under a CC-BY 4.0 International license.

Figure 3: 28 - 30 day all-cause mortality forest plot: Random effects model.

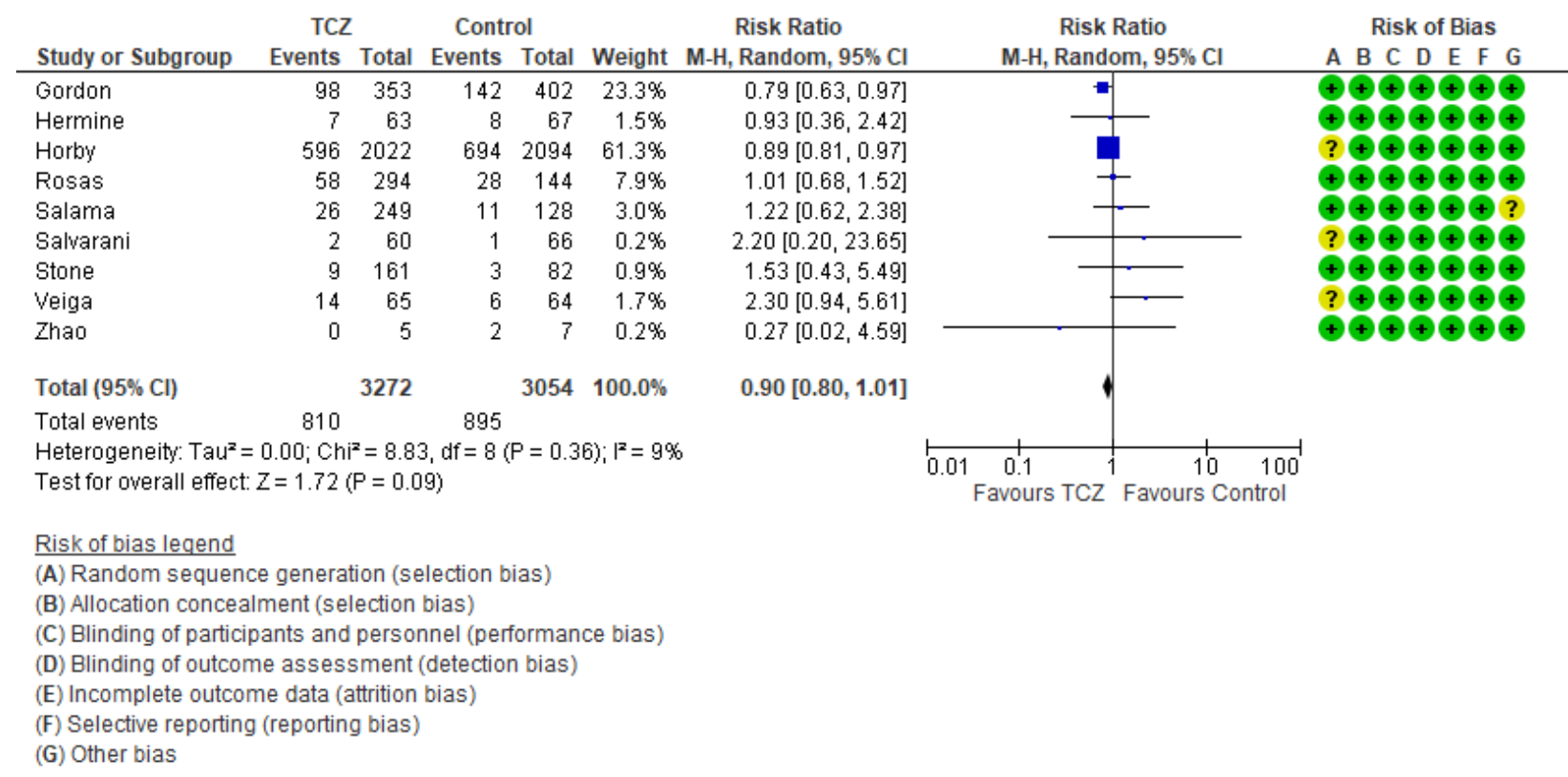


medRxiv preprint doi: https://doi.org/10.1101/2021.03.15.21253581; this version posted March 17, 2021. The copyright holder for this preprint (which was not certified by peer review) is the author/funder, who has granted medRxiv a license to display the preprint in perpetuity.

It is made available under a CC-BY 4.0 International license.

Figure 4: 28 - 30 day Mortality / Intubation / ICU admission forest plot: Random effects model.

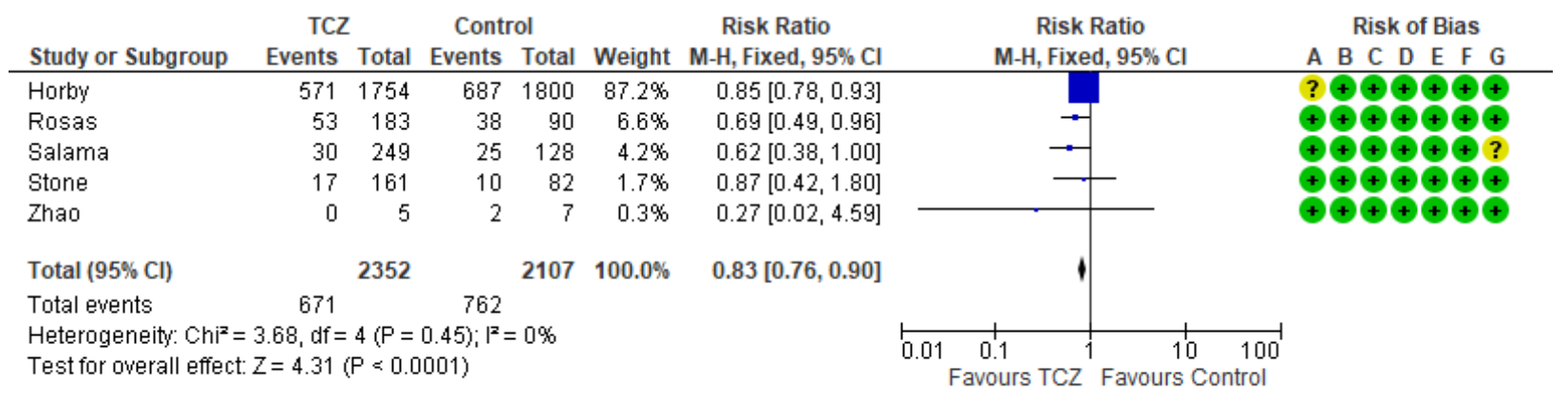

Risk of bias legend

(A) Random sequence generation (selection bias)

(B) Allocation concealment (selection bias)

(C) Blinding of participants and personnel (performance bias)

(D) Blinding of outcome assessment (detection bias)

(E) Incomplete outcome data (attrition bias)

(F) Selective reporting (reporting bias)

(G) Other bias 
medRxiv preprint doi: https://doi.org/10.1101/2021.03.15.21253581; this version posted March 17, 2021. The copyright holder for this preprint (which was not certified by peer review) is the author/funder, who has granted medRxiv a license to display the preprint in perpetuity.

It is made available under a CC-BY 4.0 International license.

Figure 5: Superadded infection forest plot: Random effects model.

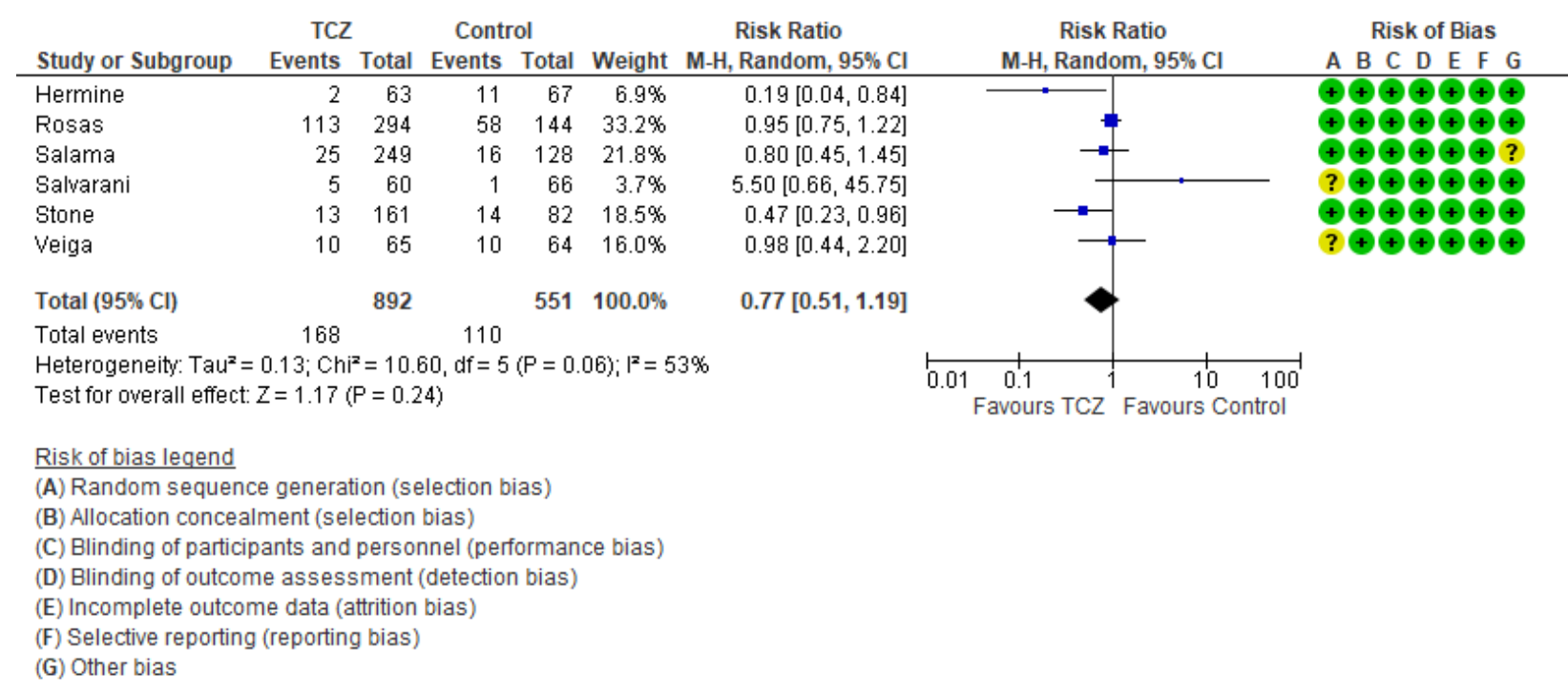


medRxiv preprint doi: https://doi.org/10.1101/2021.03.15.21253581; this version posted March 17, 2021. The copyright holder for this preprint (which was not certified by peer review) is the author/funder, who has granted medRxiv a license to display the preprint in perpetuity. It is made available under a CC-BY 4.0 International license.

Table 1: Characteristics of included studies:

\begin{tabular}{|c|c|c|c|c|c|c|c|}
\hline Study & Inclusion Criteria & Exclusion Criteria & $\begin{array}{l}\text { Tocilizumab } \\
\text { Dose }\end{array}$ & Control & $\begin{array}{l}\text { Primary } \\
\text { outcome }\end{array}$ & Blinding & Place of trial \\
\hline Stone [11] & $\begin{array}{l}19-85 \text { years, need } \mathrm{O} 2 \\
\text { to keep } \mathrm{SpO} 2>92 \%\end{array}$ & $\mathrm{O} 2>10 \mathrm{~L} / \mathrm{min}$ & $\begin{array}{l}8 \mathrm{mg} / \mathrm{kg}(\mathrm{max} \\
800 \mathrm{mg}, \text { single } \\
\text { dose }\end{array}$ & $\begin{array}{l}\text { Standard of } \\
\text { care }\end{array}$ & $\begin{array}{l}\text { Intubation or } \\
\text { death as time - } \\
\text { event analysis. }\end{array}$ & $\begin{array}{l}\text { Double } \\
\text { Blind }\end{array}$ & $\begin{array}{l}\text { USA, } \\
\text { multicenter. }\end{array}$ \\
\hline $\begin{array}{l}\text { Horby } \\
{[12]}\end{array}$ & $\begin{array}{l}\mathrm{SpO} 2<92 \% \text { on room } \\
\text { air. Could be ventilated }\end{array}$ & $\begin{array}{l}\text { hypersensitivity to } \\
\text { tocilizumab, active } \\
\text { tuberculosis } \\
\text { infection or clear } \\
\text { evidence of active } \\
\text { bacterial, fungal, } \\
\text { viral, or other } \\
\text { infection. }\end{array}$ & $\begin{array}{l}800 \mathrm{mg} \text { if } \\
\text { weight }>90 \mathrm{~kg} \text {; } \\
600 \mathrm{mg} \text { if } \\
\text { weight }>65 \text { and } \\
\leq 90 \mathrm{~kg} ; 400 \mathrm{mg} \\
\text { if weight }>40 \\
\text { and } \leq 65 \mathrm{~kg} \text {;and } \\
8 \mathrm{mg} / \mathrm{kg} \text { if } \\
\text { weight } \leq 40 \mathrm{~kg} \text { ). } \\
\text { A second dose } \\
\text { could be given } \\
12 \text { to } 24 \text { hours } \\
\text { later. }\end{array}$ & $\begin{array}{l}\text { Standard of } \\
\text { care }\end{array}$ & $\begin{array}{l}\text { All cause } 28- \\
\text { day mortality }\end{array}$ & $\begin{array}{l}\text { Open } \\
\text { Label }\end{array}$ & $\begin{array}{l}\text { U.K. } \\
\text { multicenter. }\end{array}$ \\
\hline $\begin{array}{l}\text { Hermine } \\
{[16]}\end{array}$ & $\begin{array}{l}18 \text { plus, moderate } \\
\text { pneumonia ( } 3 \mathrm{~L} / \mathrm{min} \\
\text { and } 5 \mathrm{~L} / \mathrm{min} \text { of oxygen } \\
\text { to maintain } \mathrm{SpO} 2 \\
>97 \% \text { ) } \\
\text { Severe: Respiratory } \\
\text { distress ( } \geqq 30 \text { breaths/ } \\
\text { min); Oxygen } \\
\text { saturation } \leq 93 \% \text { at rest } \\
\text { in ambient air; or } \\
\text { Oxygen saturation } \leq 97 \\
\% \text { with } \mathrm{O} 2>5 \mathrm{~L} / \mathrm{min} \text {. } \\
\mathrm{PaO} 2 / \mathrm{FiO} 2 \leqq 300 \mathrm{mmHg}\end{array}$ & $\begin{array}{l}\text { high- } \\
\text { flowoxygen(HFO) } \\
\text { more than 15 } \\
\text { L/minO2), } \\
\text { noninvasive } \\
\text { ventilation(NIV) } \\
\text { or mechanical } \\
\text { ventilation (MV) } \\
\text { and patients with } \\
\text { critical pneumonia } \\
\text { defined as WHO- } \\
\text { CPS score of } 6 \text { or } \\
\text { more (ie, with } \\
\text { HFO,NIV, or } \\
\text { MV). } \\
\text { ICU admission }\end{array}$ & $\begin{array}{l}\text { intravenously } \\
\text { (IV) at } 8 \mathrm{mg} / \mathrm{kg} \\
\text { on day } 1 . \\
\text { additional fixed } \\
\text { dose } 400 \mathrm{mg} \\
\text { IV, on day } 3 \\
\text { was } \\
\text { recommended } \\
\text { if oxygen } \\
\text { requirement } \\
\text { was not } \\
\text { decreased by } \\
\text { more than } 50 \% \text {, } \\
\text { but decision } \\
\text { was left to the } \\
\text { treating } \\
\text { physician. }\end{array}$ & $\begin{array}{l}\text { Standard of } \\
\text { care }\end{array}$ & $\begin{array}{l}\text { the proportion } \\
\text { of patients dead } \\
\text { or needing } \\
\text { noninvasive or } \\
\text { mechanical } \\
\text { ventilation on } \\
\text { day } 4\end{array}$ & $\begin{array}{l}\text { Open } \\
\text { label }\end{array}$ & $\begin{array}{l}\text { France, } \\
\text { multicenter. }\end{array}$ \\
\hline $\begin{array}{l}\text { Salama } \\
{[17]}\end{array}$ & $\begin{array}{l}18 \text { and older } \\
\text { SpO } 2<94 \% \text { while } \\
\text { breathing ambient air }\end{array}$ & $\begin{array}{l}\text { continuous } \\
\text { positive airway } \\
\text { pressure, } \\
\text { bilevel positive } \\
\text { airway pressure, or } \\
\text { mechanical } \\
\text { ventilation. }\end{array}$ & $\begin{array}{l}\text { intravenous } 8 \\
\text { mg per } \\
\text { kilogram of } \\
\text { body weight, to } \\
\text { a maximum of } \\
800 \mathrm{mg} \text { per } \\
\text { dose) } \\
\text { clinical signs or } \\
\text { symptoms } \\
\text { worsened or did } \\
\text { not improve, an } \\
\text { additional } \\
\text { infusion could } \\
\text { be administered } \\
8 \text { to } 24 \text { hours } \\
\text { after the first } \\
\text { one. }\end{array}$ & $\begin{array}{l}\text { Standard of } \\
\text { care }\end{array}$ & $\begin{array}{l}\text { mechanical } \\
\text { ventilation / } \\
\text { ECMO /or } \\
\text { death by day } \\
28 .\end{array}$ & $\begin{array}{l}\text { Double } \\
\text { Blind }\end{array}$ & $\begin{array}{l}\text { USA, Peru, } \\
\text { Brazil, } \\
\text { Kenya, South } \\
\text { Africa, } \\
\text { Mexico. }\end{array}$ \\
\hline $\begin{array}{l}\text { Salvarani } \\
{[18]}\end{array}$ & $\begin{array}{l}18 \text { or more, } \mathrm{P} / \mathrm{F} \text { ratio } \\
200-300, \\
\text { allowed to receive } \\
\text { oxygen therapy with } \\
\text { Venturi mask or high- } \\
\text { flow nasal cannula }\end{array}$ & $\begin{array}{l}\text { P/F ratio < 200, } \\
\text { MV or NIMV, } \\
\text { ICU admission, } \\
\text { Shock, Heart / } \\
\text { kidney failure }\end{array}$ & $\begin{array}{l}\text { intravenously } \\
8 \mathrm{mg} / \mathrm{kg} \text { up to a } \\
\text { maximum of } \\
800 \mathrm{mg} \text { within } \\
8 \text { hours of } \\
\text { randomization, } \\
\text { followed by a } \\
\text { second dose } \\
\text { after } 12 \text { hours. }\end{array}$ & $\begin{array}{l}\text { Standard of } \\
\text { care. }\end{array}$ & $\begin{array}{l}\text { Clinical } \\
\text { worsening } \\
\text { within } 14 \\
\text { (Admission to } \\
\text { ICU with } \\
\text { mechanical } \\
\text { ventilation } \\
\text { Death from any } \\
\text { cause }\end{array}$ & $\begin{array}{l}\text { Open } \\
\text { Label }\end{array}$ & $\begin{array}{l}\text { Italy, } \\
\text { multicenter }\end{array}$ \\
\hline
\end{tabular}


medRxiv preprint doi: https://doi.org/10.1101/2021.03.15.21253581; this version posted March 17, 2021. The copyright holder for this preprint (which was not certified by peer review) is the author/funder, who has granted medRxiv a license to display the preprint in perpetuity. It is made available under a CC-BY 4.0 International license .

\begin{tabular}{|c|c|c|c|c|c|c|c|}
\hline & & & & & $\begin{array}{l}\mathrm{PaO} 2 / \mathrm{FIO} 2 \\
\text { ratio less than } \\
150\end{array}$ & & \\
\hline Veiga [19] & $\begin{array}{l}18 \text { or more, } \\
\text { suppl O2 to keep } \mathrm{SpO} 2 \\
>93 \% \text { OR MV for less } \\
\text { than } 24 \text { hours, }\end{array}$ & $\begin{array}{l}\text { active uncontrolled } \\
\text { infection, } \\
\text { raised aspartate } \\
\text { aminotransferase } \\
\text { or alanine } \\
\text { aminotransferase } \\
\text { levels greater than } \\
\text { five times the } \\
\text { upper limit of } \\
\text { normal, } \\
\text { and renal disease } \\
\text { with an estimated } \\
\text { glomerular } \\
\text { filtration of }<30 \\
\mathrm{~mL} / \mathrm{min} / 1.72 \mathrm{~m} 2 \text {. }\end{array}$ & $\begin{array}{l}\text { single } \\
\text { intravenous } \\
\text { infusion of } 8 \\
\mathrm{mg} / \mathrm{kg} \text { ) }\end{array}$ & $\begin{array}{l}\text { Standard of } \\
\text { care. }\end{array}$ & $\begin{array}{l}\text { clinical status } \\
\text { at } 15 \text { days } \\
\text { evaluated with } \\
\text { the use of a } \\
\text { seven level } \\
\text { ordinal scale, }\end{array}$ & $\begin{array}{l}\text { Open } \\
\text { label }\end{array}$ & $\begin{array}{l}\text { Brazil, } \\
\text { multicenter. }\end{array}$ \\
\hline Zhao [20] & $\begin{array}{l}\text { more than } 18 \text { years old, } \\
\text { could be mechanically } \\
\text { ventilated }\end{array}$ & $\begin{array}{l}\text { Allergic to } \\
\text { tocilizumab; } \\
\text { Pregnant or } \\
\text { lactating } \\
\text { ALT or AST > 5 } \\
\text { times of upper } \\
\text { limit of normal; } \\
\text { active hepatitis, } \\
\text { tuberculosis, and } \\
\text { definite bacterial } \\
\text { or fungal } \\
\text { infections; }\end{array}$ & $\begin{array}{l}4-8 \mathrm{mg} / \mathrm{kg} \\
\text { (recommended } \\
400 \mathrm{mg} \text { ) } \\
\text { For patients } \\
\text { with fever, if } \\
\text { there was still } \\
\text { fever within } 24 \\
\mathrm{~h} \text { after the first } \\
\text { used, it should } \\
\text { be used once } \\
\text { more (the dose } \\
\text { was the same as } \\
\text { before). }\end{array}$ & Favipiravir & $\begin{array}{l}\text { cumulative } \\
\text { lung lesion } \\
\text { remission rate } \\
\text { (lung CT } \\
\text { examination } \\
\text { indicated } \\
\text { absorption of } \\
\text { lung } \\
\text { inflammation). }\end{array}$ & $\begin{array}{l}\text { Open } \\
\text { label }\end{array}$ & $\begin{array}{l}\text { China, } \\
\text { multicenter }\end{array}$ \\
\hline Rosas [21] & $\begin{array}{l}\geq 18 \text { years of age } \\
\text { oxygen saturation of } \\
93 \% \text { or less or a } \mathrm{P} / \mathrm{F} \\
\text { ratio of less than } 300 \\
\mathrm{~mm} \mathrm{Hg.} \\
\text { Could be mechanically } \\
\text { ventilated. }\end{array}$ & $\begin{array}{l}\text { Eminent death } \\
\text { with } 24 \text { hours, } \\
\text { tuberculosis or a } \\
\text { bacterial, fungal, } \\
\text { or viral infection } \\
\text { other than SARS- } \\
\text { CoV-2. }\end{array}$ & $\begin{array}{l}8 \mathrm{mg} \text { per } \\
\text { kilogram of } \\
\text { body weight, } \\
\text { with a } \\
\text { maximum dose } \\
\text { of } 800 \mathrm{mg} \\
\text { If clinical signs } \\
\text { or symptoms } \\
\text { did not improve } \\
\text { or worsened, a } \\
\text { second infusion } \\
\text { of tocilizumab } \\
\text { or placebo } \\
\text { could be } \\
\text { administered } 8 \\
\text { to } 24 \text { hours } \\
\text { after the first } \\
\text { dose. }\end{array}$ & $\begin{array}{l}\text { Standard of } \\
\text { care }\end{array}$ & $\begin{array}{l}\text { clinical status } \\
\text { at day } 28, \text { as } \\
\text { assessed on the } \\
\text { seven-category } \\
\text { ordinal scale. }\end{array}$ & $\begin{array}{l}\text { Double } \\
\text { Blind }\end{array}$ & $\begin{array}{l}\text { Canada, } \\
\text { Denmark, } \\
\text { France, } \\
\text { Germany, } \\
\text { Italy, the } \\
\text { Netherlands, } \\
\text { Spain, the } \\
\text { United } \\
\text { Kingdom, } \\
\text { and the } \\
\text { United States }\end{array}$ \\
\hline $\begin{array}{l}\text { Gordon } \\
\text { [22] }\end{array}$ & $\begin{array}{l}\text { >or equal } 18 \\
\text { admitted to ICU } \\
\text { receiving respiratory or } \\
\text { cardiovascular organ } \\
\text { support }\end{array}$ & Imminent death & $\begin{array}{l}8 \mathrm{mg} / \mathrm{kg} \text { of } \\
\text { actual body } \\
\text { weight (up to a } \\
\text { maximum of } \\
800 \mathrm{mg} \text { ) } \\
\text { could be } \\
\text { repeated } 12-24 \\
\text { hours later at } \\
\text { the discretion } \\
\text { of the treating } \\
\text { clinician. }\end{array}$ & $\begin{array}{l}\text { Standard of } \\
\text { care }\end{array}$ & $\begin{array}{l}\text { Respiratory and } \\
\text { cardiovascular } \\
\text { organ support } \\
\text { free days at day } \\
21 .\end{array}$ & $\begin{array}{l}\text { Open } \\
\text { label }\end{array}$ & $\begin{array}{l}\text { International } \\
\text { platform }\end{array}$ \\
\hline
\end{tabular}


Figure 2: Risk of Bias details and summary:
A: Risk of Bias Details
B: Risk of Bias Summary
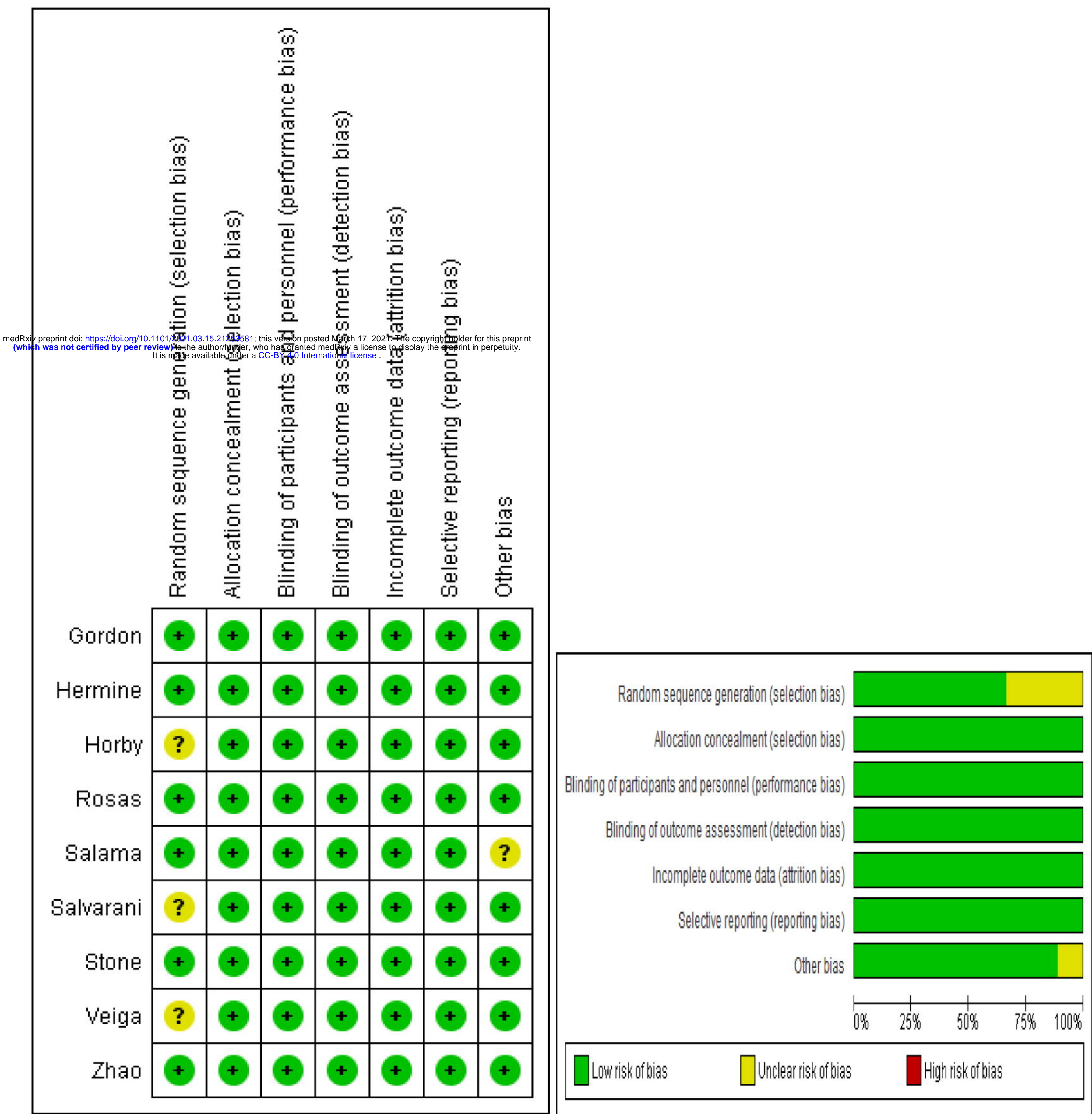
Figure 3: 28 - 30 day all-cause mortality forest plot: Random effects model.

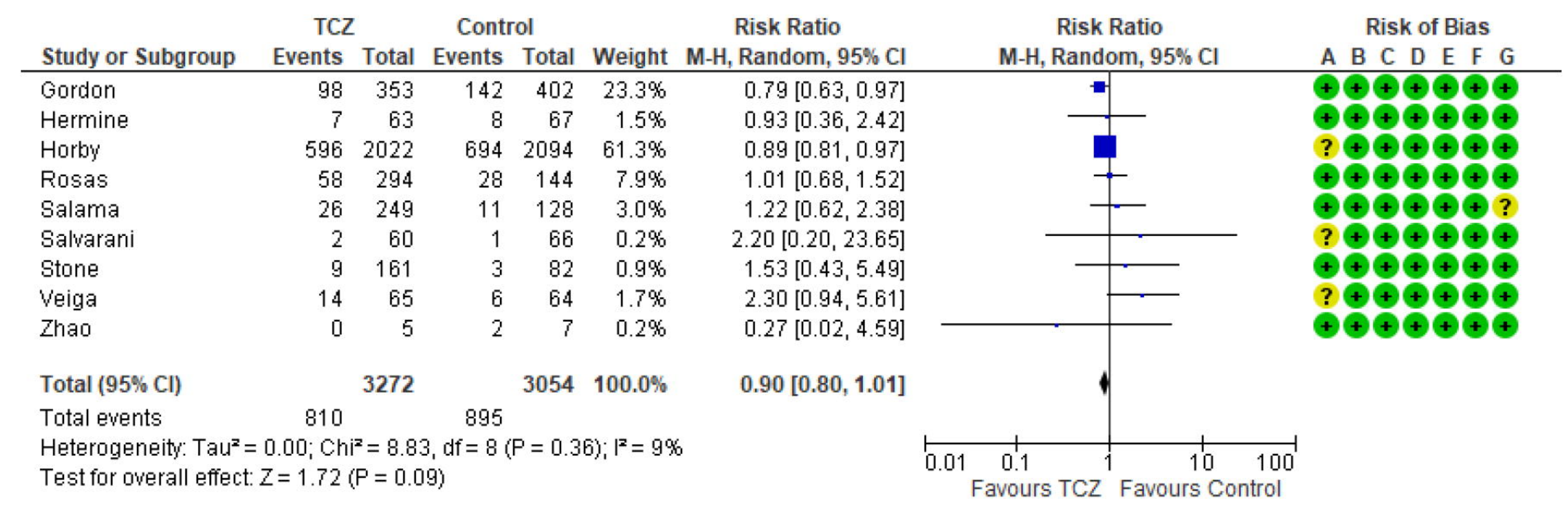

\section{Risk of bias leqend}
(A) Random sequence generation (selection bias)
(B) Allocation concealment (selection bias)
(D) Blinding of outcome assessment (detection bias)
(E) Incomplete outcome data (attrition bias)
(F) Selective reporting (reporting bias)
(G) Other bias 
Figure 5: Superadded infection forest plot: Random effects model.

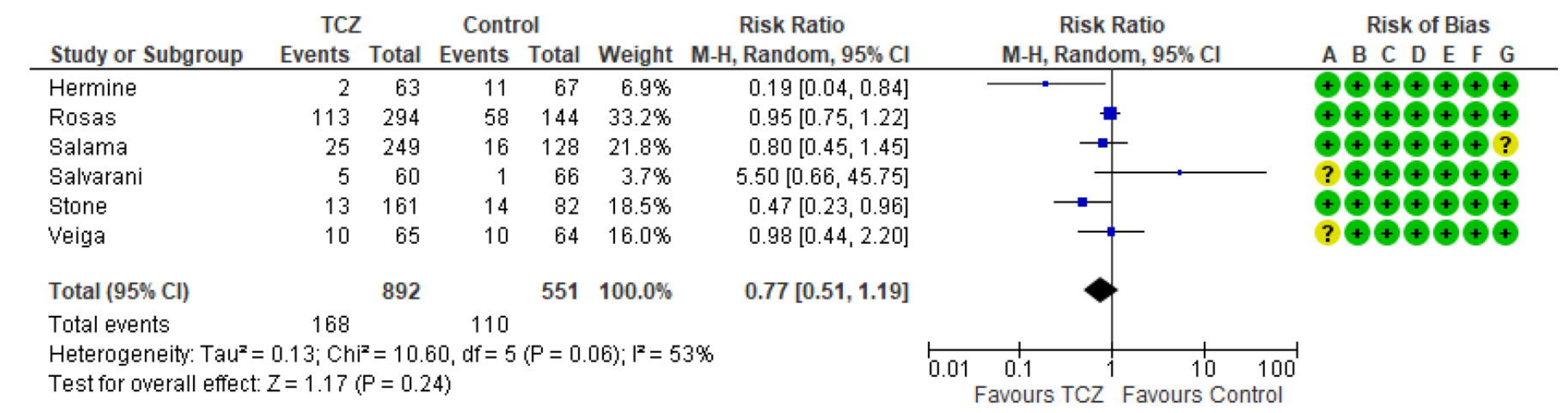

\section{Risk of bias legend}

(A) Random sequence generation (selection bias)

(B) Allocation concealment (selection bias)

(C) Blinding of participants and personnel (performance bias)

(D) Blinding of outcome assessment (detection bias)

(E) Incomplete outcome data (attrition bias)

(F) Selective reporting (reporting bias)

(G) Other bias 